\author{
V. M. Kovalyov ${ }^{1}$, A. V. Krechun ${ }^{1}$, O. O. Mykhailenko¹, O. V. Gryshyna ${ }^{2}$ \\ ${ }^{1}$ National University of Pharmacy \\ ${ }^{2}$ State Scientific Institution "Institute for Single Crystals" of the National Academy \\ of Sciences of Ukraine
}

\title{
The study of the elemental composition of Iris hungarica and varieties of irises
}

Aim. To determine the elemental composition of leaves and rhizomes of Iris hungarica and dwarf bearded irises.

Materials and methods. The objects of the study were leaves and rhizomes of Iris hungarica Waldst et Kit. and 5 varieties of standard dwarf bearded irises (Iridaceae). The content of macro- and microelements in the leaves and rhizomes of irises was determined by atomic emission spectrometry.

Results and discussion. For the first time the quantitative content of the mineral complex of Iris hungarica and dwarf bearded irises has been determined by atomic emission spectrometry. In total, 19 elements have been identified; among them there are 5 macroelements $(\mathrm{K}, \mathrm{Ca}, \mathrm{Mg}, \mathrm{Na}, \mathrm{P}), 10$ microelements elements (Fe, Si, $\mathrm{Al}, \mathrm{Mn}, \mathrm{Pl}, \mathrm{Ni}, \mathrm{Mo}, \mathrm{Cu}$, $\mathrm{Zn}, \mathrm{Sr}$ ), 4 ultramicroelements (Co, Cd, As, Hg). The content of heavy, toxic elements are within the permissible limits. The experimental data will be further used to standardize the raw material of irises.

Conclusions. The quantitative content of the mineral complex of Iris hungarica and dwarf bearded irises has been identified. According to the research results the raw material of irises can be recommended as an additional source of macro- and microelements.

Key words: irises; leaves; rhizomes; elemental composition; atomic emission spectrometry

\section{В. М. Ковальов, А. В. Кречун, О. О. Михайленко, О. В. Гришина}

\section{Дослідження елементного складу Iris hungarica та сортів півників}

Мета. Встановити елементний склад листя та кореневищ півників угорських та карликових бородатих півників.

Матеріали та методи. Об'єктами дослідження були листя та кореневища півників угорських (Iris hungarica Waldst et Kit.) та 5 сортів стандартних карликових бородатих півників (Iridaceae). Вміст макро- та мікроелементів у листі та кореневищах півників встановлювали методом атомно-емісійної спектрометрії.

Результати та їх обговорення. Вперше кількісний вміст мінерального комплексу півників угорських та карликових півників був встановлений методом атомно-емісійної спектрометрії. Були ідентифіковані 19 елементів, серед яких 5 - макроелементи (K, Ca, Mg, Na, P), 10 - мікроелементи (Fe, Si, Al, Mn, Pb, Ni, Mo, Cu, Zn, Sr), 4 - ультрамікроелементи (Co, Cd, As, Hg). Вміст важких, токсичних елементів знаходиться у допустимих межах. Дані експерименту будуть використані для стандартизації сировини півників.

Висновки. Встановлений кількісний вміст мінерального комплексу півників угорських та карликових бородатих півників. Результати досліджень можуть рекомендувати сировину півників як додаткове джерело макрота мікроелементів.

Ключові слова: півники; листя; кореневище; елементний склад; атомно-емісійна спектрометрія

\section{В.Н.Ковалев, А. В. Кречун, О. А. Михайленко, Е. В. Гришина}

\section{Исследование элементного состава Iris hungarica и сортов ирисов}

Цель. Установить элементный состав листьев и корневищ ириса венгерского и карликовых бородатых ирисов методом атомно-эмиссионной спектрометрии с дуговым возбуждением спектра.

Материалы и методы. Объектами исследования были листья и корневища ириса венгерского (Iris hungarica Waldst et Kit.) и 5 сортов стандартных карликовых бородатых ирисов (Iridaceae). Содержание макро- и микроэлементов в листьях и корневищах ирисов устанавливали методом атомно-эмиссионной спектрометрии.

Результаты и их обсуждение. Впервые количественное содержание минерального комплекса ириса венгерского и карликовых ирисов был установлен методом атомно-эмиссионной спектрометрии. Были идентифицированы 19 элементов, среди которых 5 - макроэлементы (K, Ca, Mg, Na, P), 10 - микроэлементы (Fe, Si, $\mathrm{Al}, \mathrm{Mn}, \mathrm{Pb}, \mathrm{Ni}, \mathrm{Mo}, \mathrm{Cu}, \mathrm{Zn}, \mathrm{Sr}), 4$ - ультрамикроэлементы (Co, Cd, As, Hg). Содержание тяжелых, токсических элементов находится в допустимых пределах. Данные эксперимента будут использованы для стандартизации сырья ирисов.

Выводы. Установлено количественное содержание минерального комплекса ириса венгерского и карликовых бородатых ирисов. Результаты исследований могут рекомендовать сырье ирисов как дополнительный источник макро- и микроэлементов.

Ключевые слова: ирисы; листья; корневища; элементный состав; атомно-эмиссионная спектрометрия 
Since the middle of the last century the interest in medicinal plants has increased considerably, therefore, a more detailed study of biologically active substances (BAS) of the plant origin continues [1]. The peculiarity of plants is that they are able to accumulate different groups of substances with a high biological activity, as well as vitamins, amino acids and minerals, which have also an impact on the physiological processes of both the plant itself and humans. Macro- and microelements are the integral components of plant cells, providing the normal physiological state and plant development. They can also affect the activity of one or another major BAS synthesized by a medicinal plant: they can be antagonists, synergists, or can increase or neutralize toxicity [2]. Macroelements (more than $0.01 \%$ of the content in living organisms) and microelements (less than $0.001 \%$ of the content in living organisms) are the mineral parts that are insignificant, but play an important role. These elements also perform the regulatory function within the human internal environment. For example, sodium $(\mathrm{Na})$ is one of the components that maintains the acid - base balance; calcium $(\mathrm{Ca})$ is an activator of a large number of enzymes, and is part of vitamin $\mathrm{B}_{15}$; magnesium $(\mathrm{Mg})$ takes part in nerve conduction; iron $(\mathrm{Fe})$ is the main component of hemoglobin, which provides transportation of oxygen; potassium $(\mathrm{K})$ provides the muscle contraction and osmotic pressure [3]. The presence of such elements as lead, cadmium, rubidium, lanthanum, chromium, strontium, arsenic and stibium in the medicinal raw material may indicate toxicity and environmental hazard [4]. Therefore, determination of the mineral composition of the plant raw material is an integral part of the pharmacognostic study of medicinal plants.

Continuing the research of plants of the Iridaceae family Iris hungarica and 5 varieties of dwarf bearded irises were selected at this stage of the study. Along with the already known official medicinal plants, determination of the mineral complex in the cultivated plants is an important stage when introducing them into the pharmaceutical industry. This can further lead to a future outlook of developing phytopreprations based on them.

Iris hungarica Waldst et Kit., representatives of the genus Iris L., are widely distributed on the territory of Ukraine and the near abroad. This is a perennial herbaceous plant, from 15 to $40 \mathrm{~cm}$ in height. Leaves are sharp at the ends, linearly obvious, appear later in the peduncle. The rhizome is thickened - up to $2 \mathrm{~cm}$ in diameter, with a lot of roots [5].

Standard dwarf bearded irises (SDB) are a cultivated species of irises. Due to their decorative qualities this species is widespread throughout the world. The plants reach from 21 to $40 \mathrm{~cm}$ in height, with the color of leaves varying from blue to dark green. As a rule, on the flower peduncle there are 2-4 flowers with the most diverse color of petals and beards. The rhizome is up to $2 \mathrm{~cm}$ in thickness [6].

Throughout history, irises have been used in folk medicine: they have analgesic, antiseptic [7], diuretic [8], anti-inflammatory [9], astringent [10], expectorant [11], antiviral, anti-TB effects [12]. In traditional medicine, the raw material of irises iris is part of 8 drugs and biologically active additives [13]. According to the results of the previous studies, in the raw material of Iris hungarica the following components were identified: isoflavones (daidzein, formononetin, genistein), flavonols (quercetin), hydroxycinnamic acids (cinnamic, hydroxycinnamic, ferulic, chlorogenic), phenolic acids (galic), xanthones (magniferine, isomangiferine) [14]. The substances of phenolic nature, such as tectorigenin, tectoridin, irigenin, iristectorigenin $\mathrm{B}$, iristectorin $\mathrm{B}$, daidzein, genistein, formononetin, kaempferol, quercetin, mangiferine were also isolated $[15,16]$.

The aim of this work was to determine the elemental composition of leaves and rhizomes of Iris hungarica and DSB varieties by the atomic emission spectroscopy method with an arc excitation of the spectrum.

\section{Materials and methods}

The objects of the study were leaves and rhizomes of Iris hungarica Waldst et Kit. harvested during the growing season in 2014, as well as 5 varieties of standard dwarf bearded irises: Iris $x$ hybrida hort. "Bright white", Iris $x$ hybrida hort. "Indian Pow Waw", Iris x hybrida hort. "Galleon Gold", Iris x hybrida hort. "Mini Dynamo", Iris $x$ hybrida hort. "Little Dream" were also collected during the growing season in 2016 at the M. M. Gryshko National Botanical Garden of the National Academy of Sciences of Ukraine (Kyiv).

The mineral complex was studied in the State Scientific Institution "Institute for Single Crystals" of the National Academy of Sciences of Ukraine (Department of Analytical Chemistry of Functional Materials and Objects of the Environment).

The atomic emission spectroscopy with arc excitation was used to determine the elemental composition of the objects studied.

Pre-treated by sulfuric acid the crushed raw material of the objects (3-4 $\mathrm{mm}$ ) studied was incinerated in porcelain crucibles at a temperature of $500^{\circ} \mathrm{C}$ for 1 hour in a muffle furnace. Excitation of IBS - 28 type spectra occurred in the discharge of the electric arc at the current of $16 \mathrm{~A}$ and the exposure time of 60 seconds [17]. To obtain and record the spectra of samples a DFS -8 spectrograph with diffraction gratings of $600 \mathrm{ps} / \mathrm{mm}$ and the three-line slit illumination system was used. The intensity of the emission lines was measured using a MF 4 microphotometer. The wavelength was from $240 \mathrm{~nm}$ to $347 \mathrm{~nm}$. The sample data were compared with standard samples. The results were obtained by averaging $4-5$ parallel tests and processed by the method of mathematical statistics [18].

\section{Results and discussion}

The absorption and transport of minerals reflects genotypic features (the ability to bioaccumulate chemical elements) and the conditions of the plant growth (soil composition, water regime, climatic conditions) [19]. As a result of the analysis it has been found that the ash content 
Mineral complex of leaves and rhizomes of Iris hungarica and SDB irises

\begin{tabular}{|c|c|c|c|c|c|c|c|c|c|c|c|c|c|c|c|c|c|}
\hline \multirow{2}{*}{ Sample } & \multirow{2}{*}{$\begin{array}{l}\text { The } \\
\text { study } \\
\text { object }\end{array}$} & \multicolumn{15}{|c|}{ The element content, $\mathrm{mg} / 100 \mathrm{~g}$. } & \multirow{2}{*}{ 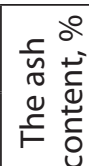 } \\
\hline & & $\mathrm{Fe}$ & $\mathrm{Si}$ & $P$ & Al & $\mathrm{Mn}$ & $\mathrm{Mg}$ & $\mathrm{Pb}$ & $\mathrm{Ni}$ & Mo & $\mathrm{Ca}$ & $\mathrm{Cu}$ & $\mathrm{Zn}$ & $\mathrm{Na}$ & K & $\mathrm{Sr}$ & \\
\hline \multirow{2}{*}{ 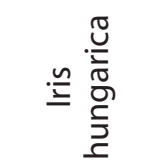 } & leaves & 20 & 815 & 100 & 35 & 0.6 & 715 & $<0.03$ & $<0.03$ & $<0.03$ & 1900 & 0.6 & 6.0 & 24 & 1190 & 24 & 11.93 \\
\hline & rhizome & 58 & 585 & 80 & 23 & 1.9 & 140 & $<0.03$ & $<0.03$ & $<0.03$ & 750 & 0.7 & 3.8 & 23 & 430 & 4.7 & 7.32 \\
\hline \multirow{2}{*}{ 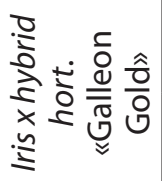 } & leaves & 15.8 & 84 & 126 & 23.1 & 6.3 & 365 & $<0.03$ & $<0.03$ & 0.031 & 1050 & 0.31 & 9.4 & 52 & 2100 & 12.6 & 10.56 \\
\hline & rhizome & 15.2 & 115 & 115 & 38 & 5.7 & 215 & $<0.03$ & 0.076 & 0.038 & 685 & 0.30 & 15.2 & 61 & 1900 & 13.7 & 7.6 \\
\hline \multirow{2}{*}{ 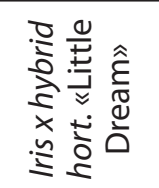 } & leaves & 20.0 & 120 & 160 & 265 & 2.0 & 400 & $<0.03$ & $<0.03$ & 0.04 & 1330 & 0.66 & 10.6 & 67 & 3990 & 20.0 & 13.3 \\
\hline & rhizome & 21.5 & 215 & 145 & 86 & 2.1 & 260 & $<0.03$ & 0.086 & 0.043 & 1030 & 0.34 & 21.5 & 60 & 2150 & 17.2 & 8.61 \\
\hline \multirow{2}{*}{ 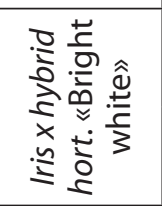 } & aves & 18.1 & 100 & 170 & 20 & 12.6 & 305 & $<0.03$ & 0.05 & 0.05 & 810 & 0.75 & 10.0 & 50 & 3030 & 15.1 & 9.63 \\
\hline & rhizome & 28.8 & 240 & 125 & 38 & 3.4 & 290 & $<0.03$ & 0.096 & 0.096 & 960 & 0.48 & 24.0 & 67 & 2880 & 17.3 & 9.6 \\
\hline \multirow{2}{*}{ 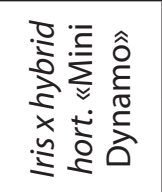 } & leaves & 12.0 & 8 & 205 & 25.8 & 2.6 & 515 & $<0.03$ & $<0.03$ & 0.086 & 1720 & 0.70 & 13.8 & 52 & 4300 & 25.8 & 17.2 \\
\hline & rhizo & 8 & 430 & 170 & 105 & 4 & 260 & 0.086 & 0.043 & 0.043 & 1030 & 0.51 & .5 & 69 & 150 & 17.2 & 8.6 \\
\hline \multirow{2}{*}{ 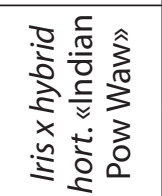 } & leaves & 17 & 115 & 170 & 34 & 4.0 & 340 & $<0.03$ & $<0.03$ & 0.056 & 1020 & 0.50 & 10.2 & 34 & 3390 & 13.5 & 11.41 \\
\hline & rhizome & 87 & 520 & 150 & 87 & 5.2 & 260 & $<0.03$ & 0.043 & $<0.03$ & 1045 & 0.43 & 17.4 & 43.5 & 1740 & 19.1 & 8.67 \\
\hline
\end{tabular}

Note. In all samples: Co < 0.03\mg/100g; Cd < 0.001 mg/100g; As < 0.001 mg/100g; $\mathrm{Hg}<0.001 \mathrm{mg} / 100 \mathrm{~g}$.

of the objects studied ranges from 7 to $17 \%$. The content of ash in rhizomes is lower (7.32-9.6\%) than in leaves (from $9.63 \%$ to $17.2 \%$ ).

In the raw materal of irises 19 elements in total were identified, among them there were 5 macroelements $(\mathrm{K}$, $\mathrm{Ca}, \mathrm{Mg}, \mathrm{Na}, \mathrm{P}), 10$ microelements elements (Fe, $\mathrm{Si}, \mathrm{Al}$, $\mathrm{Mn}, \mathrm{Pl}, \mathrm{Ni}, \mathrm{Mo}, \mathrm{Cu}, \mathrm{Zn}, \mathrm{Sr}$ ), 4 ultramicroelements (Co, $\mathrm{Cd}, \mathrm{As}, \mathrm{Hg}$ ), the quantitative content was determined (Table). There was a significant amount of potassium (430-4300 mg/100 g), calcium (685-1900 mg/100 g) and magnesium (140-715 mg/100 g). Such macroelements as phosphorus (80-205 mg/100 g) and sodium (23-69 mg/100 g) accumulated in smaller quantities (Fig. 1,2). The raw material of irises accumulated a considerable amount of silicium (84-815 mg/100 g), aluminum (20-265 mg/100 g), iron $(12.0-87 \mathrm{mg} / 100 \mathrm{~g})$, strontium $(4.7-25.8 \mathrm{mg} / 100 \mathrm{~g})$, zinc $(3.8-24 \mathrm{mg} / 100 \mathrm{~g})$. It was noted that the rhizome of irises accumulated more nickel (Ni), molybdenum (Mo) and lead $(\mathrm{Pb})$ than leaves. Such elements as cobalt $(\mathrm{Co})$, cadmium (Cd), mercury ( $\mathrm{Hg}$ ), arsenic (As) were detected within the scope of capabilities (Co $<0.03 \mathrm{mg} / 100 \mathrm{~g}$;
Cd, As, $\mathrm{Hg}<0.001 \mathrm{mg} / 100 \mathrm{~g}$ ). Heavy, toxic metals were within the permissible limits for the medicinal raw material and food products [20].

The content of the elements in the samples of the raw materal of Iris hungarica can be arranged in the following decreasing sequence of the content: for leaves $-\mathrm{Ca}>\mathrm{K}>$ $\mathrm{Si}>\mathrm{Mg}>\mathrm{P}>\mathrm{Al}>\mathrm{Fe}>\mathrm{Na}=\mathrm{Sr}>\mathrm{Zn}>\mathrm{Mn}=\mathrm{Cu}>\mathrm{Mo}=$ $\mathrm{Pb}=\mathrm{Ni}>\mathrm{Co}=\mathrm{As}=\mathrm{Hg}=\mathrm{Cd}$; for rhizomes $-\mathrm{Ca}>\mathrm{Si}>$ $\mathrm{K}>\mathrm{Mg}>\mathrm{P}>\mathrm{Fe}>\mathrm{Al}=\mathrm{Na}>\mathrm{Sr}>\mathrm{Zn}>\mathrm{Mn}>\mathrm{Cu}>\mathrm{Mo}=$ $\mathrm{Pb}=\mathrm{Ni}>\mathrm{Co}=\mathrm{As}=\mathrm{Hg}=\mathrm{Cd}$.

By the quantitative content of the elements potassium $(\mathrm{K})$, calcium $(\mathrm{Ca})$ and magnesium $(\mathrm{Mg})$ dominate, their greatest amount is accumulated in leaves of irises. Such elements as iron ( $\mathrm{Fe})$, aluminum $(\mathrm{Al})$, sodium $(\mathrm{Na})$, strontium $(\mathrm{Sr})$, zinc $(\mathrm{Zn})$ and silicium $(\mathrm{Si})$ have a higher content in rhizome of irises.

It is known that plants are able to accumulate secon dary metabolites, such as alkaloids, triterpene and phenolic compounds. In turn, the pharmacological effects of plants depend precisely on the characteristics of the chemical composition of the secondary metabolites. 


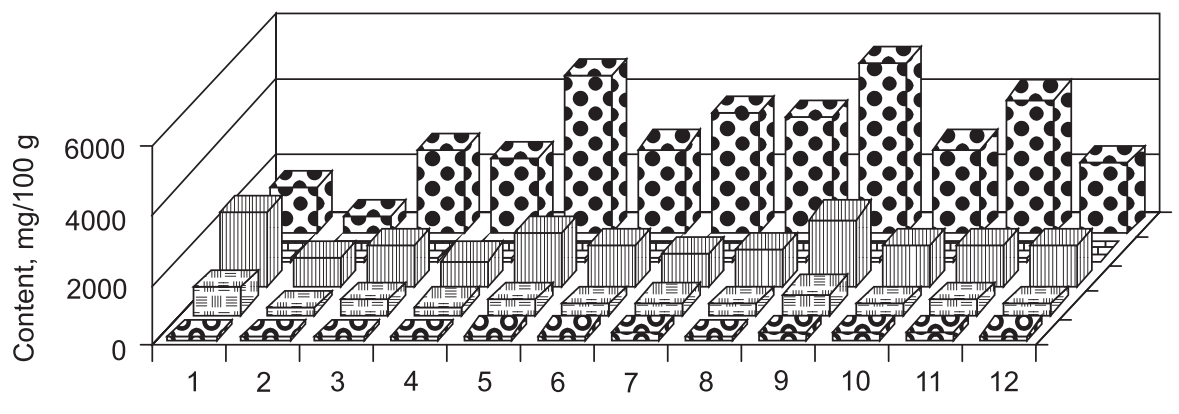

OP 国Mg 四 $\mathrm{Ca}$ 国 $\mathrm{Na}$

1 - Iris hungarica leaves

2 - Iris hungarica rhizome

3 - Iris “Galleon Gold” leaves

4 - Iris "Galleon Gold" rhizome

5 - Iris “Little Dream” leaves

6 - Iris "Little Dream" rhizome
7 - Iris "Bright white" leaves

8 - Iris "Bright white" rhizome

9 - Iris "Mini Dynamo" leaves

10 - Iris "Mini Dynamo" rhizome

11 - Iris "Indian Pow Waw" leaves

12 - Iris "Indian Pow Waw" rhizome

Fig. 1. Macroelements of irises

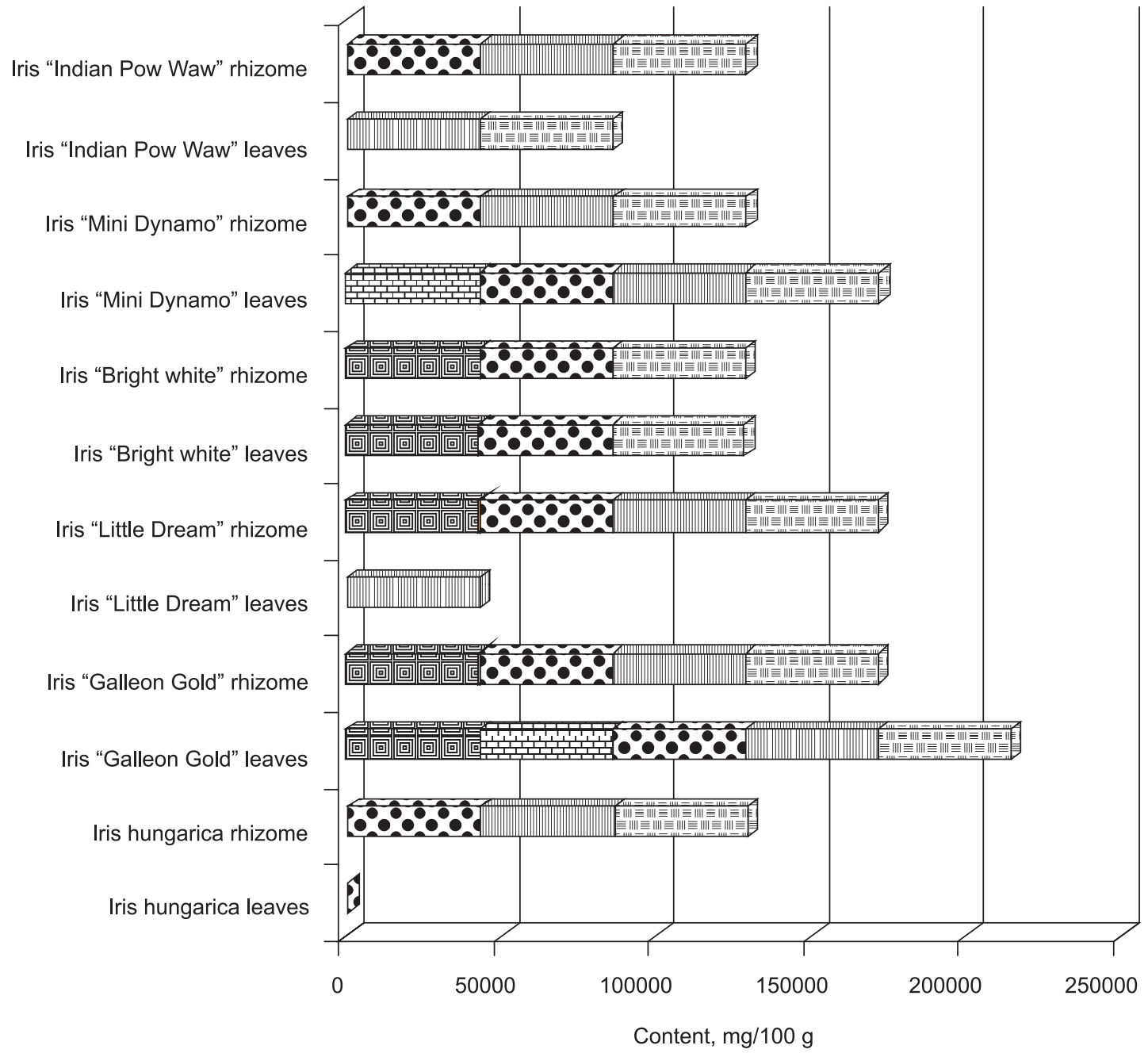

回 Fe

臣Al

Mn

皿 Zn

㟵 $\mathrm{Sr}$

Fig. 2. Microelements of irises

Note. In all samples: $\mathrm{Pb}, \mathrm{Mo}, \mathrm{Ni}, \mathrm{Co}<0.03 \mathrm{mg} / 100 \mathrm{~g} ; \mathrm{Cd}, \mathrm{As}, \mathrm{Hg}<0.001 \mathrm{mg} / 100 \mathrm{~g}$. 
Thus, phenolic compounds have a rather wide spectrum of the biological activity; they possess the anti-inflammatory, diuretic, antibacterial, hepatoprotective effect, etc. Alkaloids are characterized by different activity: cardiotonic, antitussive, antihypertensive, sympatholytic, analgesic. Triterpenes show the antitumor, hypocholesterolemic, expectorant, adaptogenic activity. The elements accumulated by the plant affect formation of certain biologically active substances. $\mathrm{Cu}, \mathrm{Mn}, \mathrm{Fe}, \mathrm{Co}$ promote the biogenesis of phenolic compounds, Mo, Mn, Sr triterpene compounds, $\mathrm{Mg}, \mathrm{Cr}$ - polysaccharides. Macroand microelements regulate not only the vital activity of the plant cell, but also affect the metabolic processes of the human body, the cardiovascular system, the immune, endocrine, nervous system, and the reproductive function in human. It is known that mineral substances are capable of neutralizing or facilitating assimilation of certain groups of biologically active substances, and are also an integral part of enzymes. Based on these data the raw material of irises can be used as an additional source of macro- and microelements.
It should be noted that varieties of irises accumulate a greater amount of potassium, sodium, phosphorus and zinc in the raw material than Iris hungarica. Iris $x$ hybrid hort. "Mini Dynamo" has the highest potassium and phosphorus content, Iris $x$ hybrid hort. "Little Dream" the sodium content. But varieties of irises have a smaller amount of calcium, magnesium and silicium than Iris hungarica.

\section{CONCLUSIONS}

For the first time the quantitative content of the mineral complex of Iris hungarica and dwarf bearded irises has been determined by atomic emission spectrometry. The content of 19 elements in leaves and rhizomes of irises has been determined. According to the research results the raw material of irises can be recommended as an additional source of macro- and microelements. Experimental data will be further used to standardize the raw material of irises. The study of plants of the genus Iris L. continues.

Conflict of Interests: authors have no conflict of interests to declare.

\section{REFERENCES}

1. Исследование антиоксидантных свойств экстрактов лекарственных растений / Г. А. Гореликова, Е. В. Шигин, Л. А. Маюрникова, Л. В. Терещу // Хранение и переработка сельхозсырья. - 2007. - № 3. - С. 26-30.

2. Macro-and microelements as possible markers of quality and authenticity for fruits and derived products / R. E. Ionete, O. R. Dinca, O. R. Geana, D. Costinel // Progress of Cryogenics \& Isotopes Separation. - 2016. - Vol. 19, № 1.

3. Galam, S. When humans interact like atoms / S. Galam // Understanding Group Behavior. - 2014. - Vol. 1. - C. $293-312$.

4. Nagajyoti, P. C. Heavy metals, occurrence and toxicity for plants: a review / P. C. Nagajyoti, K. D. Lee, T. V. M. Sreekanth // Environmental Chem. Lett. - 2010. - Vol. 8, № 3. - C. 199-216. https://doi.org/10.1007/s10311-010-0297-8

5. Krechun, A. V. Determination of quantitative composition of xanthones in the undergraund organs of Iris sibirica and Iris hungarica: The material of the conference "Topical issues of new drugs development: abstracts about international scientific and practical conference of young scientists and students". (Kharkiv, 23.04.2016) / A. V. Krechun, V. N. Kovalev, O. O. Mykhailenko. - Kharkiv : National University of Pharmacy, 2015. - 44 p.

6. Буйдин, Ю. В. Интродукционное сортоизучение представителей рода Iris L. в Национальном ботаническом саду имени Н. H. Гришко НАМН Украины: Междунар. науч. конф., посвященная 170-летию Сухумского ботанического сада, 115-летию Сухумского субтропического дендропарка, 80-летию профессора Г. Г. Айба и 105-летию профессора А. А. Колаковского (Сухум, 5-9 октября 2011). - Сухум, 2011. - С. 115-119.

7. Kovalev, V. N. A New Isoflavone from Iris pseudacorus. / V. N. Kovalev, O. A. Zatylnikova, S. V. Kovalev // Chem. of Natural Compounds. - 2013. - Vol. 49, № 1. - C. 34-35. https://doi.org/10.1007/s10600-013-0499-y

8. Asghar, S. F. Gas chromatography-mass spectrometry (GC-MS) analysis of petroleum ether extract (oil) and bio-assays of crude extract of Iris germanica / S. F. Asghar, M. I. Choudahry // Intern. J. of Genetics and Molecular Biol. - 2011. - Vol. 3, № 7. - C. 95-100.

9. Krechun, A. V. Research of the chemical composition of biologically active substances of Iris sibirica L.: The material of the conference "Topical issues of new drugs development: abstracts about the international scientific and practical conference of young scientists and students" / A. V. Krechun, O. A. Zatylnikova.- Kharkiv : National University of Pharmacy, 2013. - P. 8.

10. Krechun, A. V. Organic and hydroxycinnamic acids of Iris hungarica: Матер. респ. науч.-практ. конф. (с междунар. участием) «Актуальные вопросы образования, науки и производства в фармации» / А. V. Krechun., О. О. Mykhailenko, V. M. Kovalyov. Ташкент, 2016. - С. 6-7.

11. Antibacterial and phytochemical screening of different extracts of five Iris species growing in Kashmir / S. H. Wani, A. Amin, M. A. Rather et al. // J. of Pharm. Res. - 2012. - Vol. 5, № 6. - C. 3376-3378.

12. Free radical scavenging and antibacterial activity of essential oil and solvent extracts of Iris planifolia (Mill) from Algeria / I. Chikhi, H. Allali, M. E. A. Dib et al. // J. of Med. Plants Res. - 2012. - Vol. 6, № 10. - C. 1961-1968.

13. Antimicrobial activity of extracts of Iris hungarica and Iris sibirica / V. M. Kovalev, O. O. Mykhailenko, A. V. Krechun, T. P. Osolodchenko // Анали Мечниківського інституту. - 2017. - № 2. - С. 57-64. https://doi.org/10.5281/zenodo.803878

14. Кречун, А. В. Предварительное изучение биологически активных веществ некоторых сортов рода Iris L. методом хроматографии: Актуальные вопросы современной медицины и фармации 2017: матер. 69-й итоговой науч.-практ. конф. студентов и молодых ученых (г. Витебск, ВГМУ, 19-20 апреля 2017). / А. В. Кречун, О. А. Михайленко, В. Н. Ковалев. - Витебск : ВГМУ, 2017. - С. 199 - 200.

15. Isoflavonoids from the rhizomes of Iris hungarica and antibacterial activity of the dry rhizomes extract / O. Mykhailenko, V. Kovalyov, S. Kovalyov, A. Krechun // Ars Pharmaceutica. - 2017. - Vol. 58, № 1. - C. 39-45. 
16. Biologically active compounds from the rhizomes of Iris hungarica / O. O. Mykhailenko, V. M. Kovalyov, S. V. Kovalyov, A. V. Krechun // Журн. орг. та фармац. хімії. - 2016. - Т. 14, № 4 (56). - С. 63-66. https://doi.org/10.24959/ophcj.16.903

17. Svanberg, S. Atomic and molecular spectroscopy: basic aspects and practical applications / S. Svanberg // Springer Sci. \& Business Media, 2012.

18. Трухачёва, Н. В. Математическая статистика в медико-биологических исследованиях с применением пакета Statistica. M. : Geotar Media, 2012. - 384 c.

19. Затильнікова, О. О. Елементний склад Iris Sibirica L. // Укр. мед. альманах. - 2013. - № 16. - С. $30-31$.

20. Проблемы нормирования тяжелых металлов в лекарственном растительном сырье / О. И. Терёшкина, И. П. Рудакова, И. В. Гравель, И. А. Самылина // Фармация. - 2010. - № 2. - С. 7-11.

\section{REFERENCES}

1. Gorelikova, G. A., Shigin, E. V., Maiurnikova, L. A., Tereshchu, L. V. (2007). Khranenie i pererabotka selkhozsyria, 3, $26-30$.

2. Ionete, R. E., Dinca, O. R., Geana, E. I., Costinel, D. (2016). Macro-and microelements as possible markers of quality and authenticity for fruits and derived products. Progress of Cryogenics \& Isotopes Separation, 19 (1).

3. Galam S. (2014). When humans interact like atoms. Understanding group behavior, 1, 293-312.

4. Nagajyoti, P. C., Lee, K. D., \& Sreekanth, T. V. M. (2010). Heavy metals, occurrence and toxicity for plants: a review. Environmental Chemistry Letters, 8 (3), 199-216. https://doi.org/10.1007/s10311-010-0297-8

5. Krechun, A. V., Kovalev, V. N., Mykhailenko, O. O. (2015). Determination of quantitative composition of xanthones in the undergraund organs of Iris sibirica and Iris hungarica: The material of the conference "Topical issues of new drugs development: abstracts about international scientific and practical conference of young scientists and students" (Kharkiv 23. 04. 2015 ). Kharkiv: NPaU, 44.

6. Buydin, Yu. V. (2011). Mezhdunarodnaia nauchnaia konferentciia posviashchennaia 170-letiiu Sukhumskogo botanicheskogo sada, 115-letiiu Sukhumskogo subtropicheskogo dendroparka, 80-letiiu professora G. G. Aiba i 105-letiiu professora A. A. Kolakovskogo. (Sukhum, 5-9. 10. 2011). Sukhum, 115-119.

7. Kovalev, V. N., Zatyl'nikova, O. A., \& Kovalev, S. V. (2013). A New Isoflavone from Iris pseudacorus. Chemistry of Natural Compounds, 49 (1), 34-35. https://doi.org/10.1007/s10600-013-0499-y

8. Asghar, S. F., Choudahry, M. I. (2011). Gas chromatography-mass spectrometry (GC-MS) analysis of petroleum ether extract (oil) and bio-assays of crude extract of Iris germanica. Inter. International Journal of Genetics and Molecular Biology; 3 (7), $95-100$.

9. Krechun, A. V., Zatylnikova, O. A. (2013). Research of the chemical composition of biologically active substances of Iris sibirica L.: The material of the conference "Topical issues of new drugs development: abstracts about the international scientific and practical conference of young scientists and students". Kharkiv, 8.

10. Krechun, A. V., Mykhailenko, O. O., Kovalyov, V. M. (2016). Organic and hydroxycinnamic acids of Iris hungarica: Materials of the republican scientific-practical conference (with international participation) "Actual issues of education, science and production in pharmacy". Tashkent, 6-7.

11. Wani, S. H., Amin, A., Rather, M. A., Parray, J., Parvaiz, A. Qadri, R. A. (2012). Antibacterial and phytochemical screening of the different extracts of five Iris species growing in Kashmir. Journal of pharmaceutical research, 5 (6), 3376-3378.

12. Chikhi, I., Allali, H., Dib, M. E. A., Halla, N., Muselli, A., Tabti, B., Costa, J. (2012). Free radical scavenging and antibacterial activity of essential oil and solvent extracts of Iris Planifolia (Mill) from Algeria. Journal of Medicinal Plants Research, 6 (10), $1961-1968$.

13. Kovalev, V. M., Mykhailenko, O. O., Krechun, A. V., Osolodchenko, T. P. (2017). Antimicrobial activity of extracts of Iris hungarica and Iris sibirica. Annals of Mechnikov institute, 2, 57-64. https://doi.org/10.5281/zenodo.803878

14. Krechun, A. V., Mikhaylenko, O. A., Kovalev, V. N. (2017). Predvaritelnoe izuchenie biologicheski aktivnykh veshchestv nekotorykh sortov roda Iris L. metodom khromatografi: Aktualnye voprosy sovremennoi meditciny i farmatcii 2017: materialy 69-i itogovoi nauchno-prakticheskoi konferentcii studentov i molodykh uchenykh. (Vitebsk, 19-20. 04. 2017). Vitebsk: VSMU, 199 -200.

15. Mykhailenko, O., Kovalyov, V., Kovalyov, S., Krechun, A. (2017). Isoflavonoids from the rhizomes of Iris hungarica and antibacterial activity of the dry rhizomes extract. Ars Pharmaceutica, 58 (1), 39-45.

16. Mykhailenko, O. O., Kovalyov, V. M., Kovalyov, S. V., \& Krechun, A. V. (2016). Biologically active compounds from the rhizomes of Iris hungarica. Žurnal organičnoï ta farmacevtičnoï himiï, 14 (4 (56)), 63-66. https://doi.org/10.24959/ophcj.16.903

17. Svanberg S. (2012). Atomic and molecular spectroscopy: basic aspects and practical applications. Springer Science \& Business Media.

18. Trukhacheva, N. V. (2012). Matematicheskaia statistika v mediko-biologicheskikh issledovaniiakh s primeneniem paketa Statistica. Moskva, Rossiia: Geotar Media, 384.

19. Zatylnikova, O. O. (2013). Ukrainskyi medychnyi almanakh, 16, 30-31.

20. Tereshkina, O. I., Rudakova, I. P., Gravel, I. V., Samylina, I. A. (2010). Farmatciia, 2, 7-11. 


\section{Information about authors:}

Kovalyov V. M., Doctor of Pharmacy (Dr. habil.), professor of the Pharmacognosy Department, National University of Pharmacy. E-mail: gnosy@nuph.edu.ua Krechun A. V., postgraduate student of the Pharmacognosy Department, National University of Pharmacy. E-mail: ana2017krechun@gmail.com. ORCID: http://orcid.org/0000-0001-5545-9415

Mykhailenko O. O., Candidate of Pharmacy (Ph.D.), teaching assistant of the Botany Department, National University of Pharmacy. E-mail: zolya85@gmail.com Gryshyna O. V., senior engineer, State Scientific Institution “Institute for Single Crystals" of the National Academy of Sciences of Ukraine. E-mail: helen_g15@ukr.ne Відомості про авторів:

Ковальов В. М., д-р фарм. наук, професор кафедри фармакогнозії, Національний фармацевтичний університет. E-mail: gnosy@nuph.edu.ua Кречун А. В., аспірант кафедри фармакогнозії, Національний фармацевтичний університет. E-mail: ana2017krechun@gmail.com,

ORCID: http://orcid.org/0000-0001-5545-9415

Михайленко О. О., канд. фарм. наук, асистент кафедри ботаніки, Національний фармацевтичний університет. E-mail: zolya85@gmail.com

Гришина О. В., старший інженер, Державний науковий інститут «Інститут монокристалів» Національної Академії Наук України. Е-таil: helen_g15@ukr.net Сведения об авторах:

Ковалёв В. Н., д-р фарм. наук, профессор кафедры фармакогнозии, Национальный фармацевтический университет. E-mail: gnosy@nuph.edu.uа Кречун А. В., аспирант кафедры фармакогнозии, Национальный фармацевтический университет. E-mail: ana2017krechun@gmail.com. ORCID: http://orcid.org/0000-0001-5545-9415

Михайленко О. А., канд. фарм. наук, ассистент кафедры ботаники, Национальный фармацевтический университет. E-mail: zolya85@gmail.com Гришина Е. В., старший инженер, Государственный научный институт «Институт монокристаллов» Национальной Академии Наук Украины. E-mail: helen_g15@ukr.net 